\title{
Penerapan Sistem Akuntabilitas Kinerja Instansi Pemerintah (SAKIP) Dalam Mewujudkan Good Governance Pada Politeknik Negeri Padang
}

\author{
Wiwik Andriani \\ Irda Rosita \\ Hidayatul Ihsan \\ Jurusan Akuntansi Politeknik Negeri Padang
}

\begin{abstract}
Government Performance Accountability Report (LAKIP) as a part of Government Performance Accountability System (SAKIP) has an important role in good governance implementation in every government agency. This study aims to observe the implementation of SAKIP in oreder to achieve good governance in Padang State of Polytechnic (PNP). Based on LAKIP review by Directorate General of Higher Education in 2011, PNP got "Adequate" result. The LAKIP review result increased in 2012 and 2013. Data was collected through questionnaires based on government agency performance accountability woking paper relesed in Regulation of the Minister of State for Administrative Reform and Bureaucratic Reform Number 13/2010. Items to be evaluated are (1) performance planning (Strategic Plan/Renstra), Annual Performace Plan/Renja, and Performance Establisment), (2) performance meaurement, (3) performance repoting, (4) performance evaluation, and (5) performance achievement.
\end{abstract}

Keyword : SAKIP, LAKIP, Performance Accountability, Politeknik Negeri Padang

\section{Pendahuluan}

Semenjak terjadinya krisis moneter pada tahun 1997 yang lalu, masyarakat sudah semakin kritis. Masyarakat menginginkan akuntabilitas pada lembaga-lembaga publik baik di tingkat pusat maupun daerah. Akuntabilitas publik secara umum dimaksudkan untuk memberikan informasi atas aktifitas dan kinerja financial pemerintah kepada pihak-pihak yang berkepentingan dengan laporan tersebut. Menurut Mardiasmo, 2004, akuntabilitas publik dapat diartikan sebagai bentuk kewajiban pihak pemegang amanah (agent) untuk memberikan pertanggungjawaban, menyajikan, melaporkan dan mengungkapkan segala aktivitas dan kegiatan yang menjadi tanggungjawabnya kepada pihak pemberi amanah. Terwujudnya akuntabilitas inilah yang merupakan tujuan utama dari reformasi sektor publik.
Saat sekarang ini, pemerintah tidak dapat lagi melaksanakan kegiatan tanpa adanya pertanggungjawaban yang jelas pada masyarakat. Tidak sama seperti zaman orde baru dimana instansi pemerintah hanya mengukur dan melaporkan kepatuhan instansi pemerintah terhadap batasan anggaran yang telah ditetapkan. Banyak kegiatan yang telah dilaksanakan tapi sebenarnya tidak bermanfaat bagi masyarakat. Kegiatan yang dilakukan kurang adanya pertimbangan akan cost dan benefits.

Dengan sistem seperti dijelaskan di atas, tidak dapat mengukur kinerja instansi pemerintah apakah sudah dilaksanakan dengan baik atau belum karena tidak adanya indikator untuk menilai kinerja, visi, misi dan tujuan yang ingin dicapai oleh suatu organisasi pemerintah. Apalagi lembaga pemerintahan khususnya Politeknik Negeri Padang sangat dituntut 
untuk melaksanakan kegiatannya sesuai dengan Renstra yang telah dibuat. Di dalam Renstra tersebut akan tergambar dengan jelas, apa yang akan dicapai atau diwujudkan 5 (lima) tahun mendatang.

Oleh karena itu, pada tahun 1998 keluarlah TAP MPR RI No XI/MPR/1998 tentang penyelenggaraan negara yang bersih dan bebas korupsi, kolusi dan nepotisme. Kemudian dilanjutkan dengan keluarnya Instruksi Presiden Republik Indonesia Nomor 7 Tahun 1999 tentang Akuntabilitas Kinerja Instansi Pemerintah. Di dalam Inpres Nomor 7 Tahun 1999 dinyatakan bahwa dalam rangka lebih meningkatkan pelaksanaan pemerintahan yang lebih berdaya guna, berhasil guna, bersih dan bertanggungjawab, maka laporan akuntabilitas kinerja instansi pemerintah perlu dibuat agar dapat diketahui kemampuan organisasi pemerintah dalam mencapai visi, misi dan tujuan yang telah ditetapkan.

Laporan Akuntabilitas Kinerja Instansi Pemerintah (LAKIP) merupakan perwujudan dari pelaksanaan SAKIP (Sistem Akuntabilitas Kinerja Instansi Pemerintah) yang dibuat untuk meningkatkan pelaksanaan pemerintah yang bersih sehingga good governance dapat diwujudkan.

Politeknik Negeri Padang merupakan suatu bentuk organisasi publik yang memberikan jasa kepada masyarakat, sudah sepatutnya memberikan kinerja yang baik. Kita ketahui bahwa orang yang menjalankan Politeknik Negeri Padang berasal dari orang-orang yang berkualitas dan sangat profesional dibidangnya, oleh sebab itu maka sudah selayaknyalah memberikan pelayanan yang berkualitas pula.

Dalam jangka panjang, mutu merupakan hal yang terpenting bagi lembaga pendidikan. Lembaga pendidikan yang bermutu akan dicari oleh masyarakat, namun lembaga pendidikan yang tidak bermutu hanya menjadi penggembira saja. Dalam PP No. 60 tahun 1999 tentang Pendidikan Tinggi, pengertian mutu Perguruan Tinggi adalah keterkaitan antara tujuan, masukan, proses dan keluaran yang merupakan tanggung jawab institusional Perguruan Tinggi masing-masing (Pasal 128 ayat 2). Mutu Perguruan Tinggi dijelaskan pada penjelasan Pasal 128 ayat 2 terdiri atas efektifitas, efisiensi, produktifitas, akuntabilitas, suasana akademik dan ketahanan sistem.

Mengingat mutu sangat penting pada lembaga pendidikan khususnya di Perguruan Tinggi, maka untuk mewujudkan ini Perguruan Tinggi harus akuntabel dalam mengelola institusinya. Oleh karena itu penulis tertarik melaksanakan penelitian dengan judul "Penerapan Sistem Akuntabilitas Kinerja Instansi Pemerintah (SAKIP) dalam Mewujudkan Good Governance pada Politeknik Negeri Padang."

\section{Perumusan Masalah}

Berdasarkan uraian di atas maka permasalahan yang dirumuskan adalah sebagai berikut :

1. Bagaimanakah tingkat akuntabilitas kinerja instansi pada Politeknik Negeri Padang?

2. Apakah Sistem Akuntabilitas Kinerja Instansi Pemerintah yang telah dibuat dapat mencapai Good Governance atau dengan kata lain apakah benar SAKIP mampu mewujudkan Good Governance pada Politeknik Negeri Padang?

3. Permasalahan apa saja yang dihadapi oleh Politeknik Negeri Padang?

\section{Tujuan Penelitian}

Tujuan dari penelitian ini adalah :

1. Untuk mengetahui tingkat akuntabilitas kinerja instansi pada Politeknik Negeri Padang.

2. Untuk mengetahui dan menganalisis apakah Sistem Akuntabilitas Kinerja Instansi Pemerintah yang telah dibuat pada instansi ini mampu mewujudkan Good Governance pada Politeknik Negeri Padang.

3. Untuk mengetahui dan menganalisis permasalahan yang dihadapi oleh PT dan bagaimana solusi untuk mengatasinya. 


\section{Manfaat Penelitian}

Dari penelitian, maka manfaat yang dapat diperoleh adalah sebagai berikut :

1. Memperkaya referensi dalam bidang kajian Akuntansi Pemerintahan dan Lembaga non Profit.

2. Bahan masukan bagi Politeknik Negeri Padang dalam upaya menciptakan mutu dan pelayanan yang baik.

3. Sebagai informasi yang sangat penting bagi pengelola Politeknik Negeri Padang untuk mengetahui seberapa besar pengaruh SAKIP dapat mewujudkan Good Governance pada Politeknik Negeri Padang.

4. Penelitian ini sangat penting dilaksanakan mengingat semakin besarnya tuntutan masyarakat yang menginginkan akuntabilitas yang baik kepada masyarakat atas pengelolaan lembaga ini.

\section{Metodologi Penelitian}

Penelitian ini mengambil objek tentang SAKIP dan Good Governance, sedangkan yang menjadi unit observasinya adalah Politeknik Negeri Padang. Tipe penelitian ini merupakan analisis deskriptif yang digunakan untuk mengetahui dan menganalisis SAKIP dapat mewujudkan Good Governance pada Politeknik Negeri Padang. Sumber data berasal dari data sekunder berupa Pedoman Penyusunan LAKIP dan laporan berupa LAKIP tahun 2012 dan 2013 dari masing-masing objek yang akan diteliti. Selain data sekunder terlebih dahulu peneliti memberikan kuisioner dalam bentuk kertas kerja dari Peraturan Menteri Negara Pendayagunaan Aparatur Negara dan Reformasi Birokrasi Nomor 13 Tahun 2010 untuk diisi oleh responden. Kemudian dilanjutkan dengan wawancara secara detail dan mendalam dari masing-masing PTN. Wawancara dilakukan dengan pihak-pihak yang berkompeten dan berkepentingan dalam penyusunan LAKIP dari masing-masing PTN. Data yang diisi secara kuisioner akan di cros check dengan melakukan wawancara mendalam. Setelah mendapatkan informasi dan data yang lengkap maka akan dianalisis dengan menggunakan metode kualitatif.

\section{Tinjauan Pustaka}

\section{Pengertian Akuntabilitas}

Seperti kita ketahui pada saat sekarang ini bahwa tuntutan masyarakat sangat besar terhadap penyelenggaraan pemerintah yang baik dan bersih (good governance) sehingga mendorong pemerintah untuk menerapkan sistem pertanggungjawaban yang jelas, tepat, teratur dan efektif. Hal ini harapan yang sangat besar dari masyarakat Indonesia. Pertanggungjawaban yang jelas, tepat dan efektif akan sangat berdampak terhadap pengelolaan yang baik sehingga masyarakat akan lebih percaya dan pada akhirnya kesejahteraan masyarakat akan dapat lebih ditingkatkan.

Banyak ahli yang menyatakan pengertian akuntabilitas, diantaranya menurut Mardiasmo (2004, 20) menyatakan bahwa :

Akuntabilitas publik adalah kewajiban pihak pemegang amanah (agent) untuk memberikan pertanggungjawaban, menyajikan, melaporkan dan mengungkapkan segala aktifitas dan kegiatan yang menjadi tanggungjawabnya kepada pihak pemberi amanah (principal) yang memiliki hak dan kewenangan untuk meminta pertanggungjawaban tersebut.

Dalam konteks organisasi pemerintah, akuntabilitas publik adalah pemberian informasi dan disclosure atas aktifitas dan kinerja finansial pemerintah kepada pihak-pihak yang berkepentingan dengan laporan tersebut. Pemerintah harus bisa menjadi subjek pemberi informasi dalam rangka pemenuhan hak-hak publik. Tuntutan akuntabilitas publik mengharuskan lembaga-lembaga sektor publik untuk lebih menekankan pada pertanggungjawaban horizontal bukan hanya pertanggungjawaban vertikal.

Jenis akuntabilitas publik terdiri dari 2 (dua) macam menurut Mardiasmo, yaitu :

a. Akuntabilitas vertikal

Pertanggungjawaban vertikal merupakan pertanggungjawaban atas 
pengelolaan dana kepada otoritas yang lebih tinggi, misalnya pertanggungjawaban unit-unit kerja (dinas) kepada pemerintah daerah, pertanggungjawaban pemerintah daerah kepada pemerintah pusat dan pemerintah pusat kepada MPR.

b. Akuntabilitas horizontal

Pertanggungjawaban horizontal merupakan pertanggungjawaban kepada masyarakat luas.

Menurut Ellwood (1993) dalam Mardiasmo (2004, 21) menjelaskan bahwa terdapat empat dimensi akuntabilitas yang harus dipenuhi oleh organisasi sektor publik yaitu :

1. Akuntabilitas kejujuran dan akuntabilitas hukum.

Akuntabilitas ini terkait dengan penghindaran penyalahgunaan jabatan sedangkan akuntabilitas hukum terkait dengan jaminan adanya kepatuhan hukum dan peraturan lain yang disyaratkan dalam penggunaan sumber dana publik.

2. Akuntabilitas proses

Akuntabilitas proses terkait dengan apakah prosedur yang digunakan dalam melaksanakan tugas sudah cukup baik dalam hal kecukupan sistem informasi akuntansi, sistem informasi manajemen dan prosedur administrasi.

3. Akuntabilitas program

Akuntabilitas program terkait dengan pertimbangan apakah tujuan yang ditetapkan dapat dicapai atau tidak, dan apakah telah mempertimbangkan alternative program yang memberikan hasil yang optimal dengan biaya yang minimal.

4. Akuntabilitas kebijakan

Akuntabilitas kebijakan terkait dengan pertanggungjawaban pemerintah, baik pusat maupun daerah atas kebijakankebijakan yang diambil pemerintah terhadap DPR/DPRD dan masyarakat luas.

Berdasarkan Pedoman Penyusunan Pelaporan Akuntabilitas Kinerja Instansi Pemerintah yang ditetapkan oleh Kepala Lembaga Administrasi Negara, dalam modul Akuntabilitas Instansi Pemerintah, BPKP, 2007 menyatakan bahwa pelaksanaan Akuntabilitas Kinerja
Instansi Pemerintah harus berdasarkan prinsip berikut ini :

1. Adanya komitmen dari pimpinan dan seluruh staf instansi yang bersangkutan

2. Berdasarkan suatu sistem yang dapat menjamin penggunaan sumbersumber daya secara konsisten dengan peraturan perundangundangan yang berlaku.

3. Menunjukkan tingkat pencapaian sasaran dan tujuan yang telah ditetapkan.

4. Berorientasi pada pencapaian visi dan misi serta hasil dan manfaat yang diperoleh

5. Jujur, objektif, transparan dan akurat

6. Menyajikan keberhasilan/kegagalan dalam pencapaian sasaran dan tujuan yang telah ditetapkan.

7. Adanya pengawasan dan penilaian terhadap akuntabilitas kinerja instansi pemerintah.

Dalam menciptakan akuntabilitas erat kaitannya dengan konsep value for money yaitu :

1. Ekonomi : perolehan input dengan kualitas dan kuantitas tertentu pada harga yang terendah. Ekonomi merupakan perbandingan input dan input value yang dinyatakan dalam satuan moneter.

2. Efisiensi : pencapaian output yang maksimum dengan input tertentu atau penggunaan input yang terendah untuk mencapai output tertentu. Efisiensi merupakan perbandingan output/input yang dikaitkan dengan standar kinerja atau target yang telah ditetapkan.

3. Efektifitas : tingkat pencapaian hasil program dengan target yang ditetapkan. Secara sederhana efektifitas merupakan perbandingan outcome dengan output.

\section{SAKIP dan LAKIP}

SAKIP merupakan singkatan dari Sistem Akuntabilitas Kinerja Instansi Pemerintah sedangkan LAKIP singkatan dari Laporan Akuntabilitas Kinerja Instansi Pemerintah. Dalam Modul BPKP tentang Akuntabilitas Instansi Pemerintah, Edisi Kelima, 2007 menyatakan bahwa Sistem Akuntabilitas Kinerja Instansi Pemerintah merupakan 
suatu tatanan, instrument dan metode pertanggungjawaban yang intinya meliputi tahap-tahap sebagai berikut :

1. Penetapan perencanaan strategik

2. Pengukuran kinerja

3. Pelaporan kinerja

4. Pemanfaatan informasi kinerja bagi perbaikan kinerja secara berkesinambungan.

Selanjutnya capaian kinerja tersebut dilaporkan kepada pihak yang berkepentingan dalam bentuk Laporan Akuntabilitas Kinerja Instansi Pemerintah (LAKIP). LAKIP merupakan bahagian dari SAKIP, dimana informasi yang termuat dalam LAKIP ini akan dimanfaatkan untuk perbaikan kinerja instansi secara berkesinambungan.

Penyusunan LAKIP berdasarkan siklus anggaran yang berjalan yaitu 1 (satu) tahun. Secara lengkap LAKIP memuat laporan yang membandingkan perencanaan dan hasil yang telah diperoleh. Laporan akuntabilitas kinerja instansi pemerintah (LAKIP) sebuah laporan yang berisikan akuntabilitas dan kinerja dari suatu instansi pemerintah.

Dalam LAKIP berisi tentang kinerja instansi dan akuntabilitasnya yaitu gambaran mengenai tingkat pencapaian pelaksanaan suatu kegiatan/program/ kebijakan dalam visi, misi, tujuan, sasaran organisasi dan merupakan media akuntabilitas setiap instansi.

Dalam LAKIP ada 4 (empat) dokumen penting di dalamnya yang dinilai yaitu :

a. Renstra (Rencana Strategik)

Perencanaan Strategik merupakan langkah awal yang harus dilakukan oleh suatu organisasi. Dalam renstra tersebut memuat visi, misi, tujuan, sasaran dan strategi (kebijakan dan program) yang jelas dan mempunyai indikator yang jelas untuk mencapainya.

b. Perencanaan Kinerja (Renja)

Merupakan proses perencanaan kinerja sebagai penjabaran dari sasaran dan program yang telah ditetapkan dalam Renstra melalui berbagai kegiatan tahunan. Setiap kegiatan dilengkapi dengan indikatorindikator kinerja input, output, benefit dan impact yang disertai dengan indikator dan rencana tingkat capaiannya.

c. Pengukuran Kinerja

Merupakan metoda pengukuran yang membandingkan antara rencana kinerja dengan capaian masingmasing indikator sasaran maupun indikator kinerja kegiatan (input, output, outcomes, benefits dan impacts).

d. Evaluasi Kinerja

Kegiatan ini untuk mengetahui pencapaian realisasi setiap indikator kinerja kegiatan, kemajuan dan kendala yang dijumpai dalam mencapai visi, misi agar dapat dinilai dan dipelajari untuk perbaikan kinerja dalam pelaksanaan program/kegiatan yang akan datang. Kemudian dilakukan analisis efisiensi dengan cara membandingkan antara output dengan input baik untuk rencana maupun realisasi sehingga dapat memberikan gambaran tingkat efisiensi yang dilakukan oleh instansi tersebut.

Setiap komponen dan sub komponen penilaian diberikan alokasi nilai sebagai berikut :

\begin{tabular}{|c|c|c|c|c|}
\hline No & Komponen & Bobot & & Sub Komponen \\
\hline \multirow[t]{3}{*}{1} & $\begin{array}{l}\text { Perencana } \\
\text { n Kinerja }\end{array}$ & $35 \%$ & a & $\begin{array}{l}\text { Rencana Strategis } \\
15 \%\end{array}$ \\
\hline & & & $\mathrm{b}$ & $\begin{array}{ll}\text { Rencana } & \text { Kinerja } \\
\text { Tahunan } 10 \% & \end{array}$ \\
\hline & & & C & $\begin{array}{l}\text { Penetapan Kinerja } \\
10 \%\end{array}$ \\
\hline \multirow[t]{3}{*}{2} & $\begin{array}{l}\text { Pengukura } \\
\text { n Kinerja }\end{array}$ & $20 \%$ & $a$ & $\begin{array}{l}\text { Pemenuhan } \\
\text { pengukuran } 4 \%\end{array}$ \\
\hline & & & $\mathrm{b}$ & $\begin{array}{l}\text { Kualitas pengukuran } \\
10 \%\end{array}$ \\
\hline & & & c & $\begin{array}{l}\text { Implementasi } \\
\text { pengukuran } 6 \%\end{array}$ \\
\hline \multirow[t]{3}{*}{3} & $\begin{array}{l}\text { Pelaporan } \\
\text { Kinerja }\end{array}$ & $15 \%$ & $\mathrm{a}$ & $\begin{array}{l}\text { Pemenuhan } \\
\text { pelaporan } 3 \%\end{array}$ \\
\hline & & & $\mathrm{b}$ & $\begin{array}{l}\text { Penyajian informasi } \\
\text { kinerja } 8 \%\end{array}$ \\
\hline & & & c & $\begin{array}{l}\text { Pemanfaatan } \\
\text { informasi kinerja 4\% }\end{array}$ \\
\hline \multirow[t]{3}{*}{4} & $\begin{array}{l}\text { Evaluasi } \\
\text { Kinerja }\end{array}$ & $10 \%$ & $a$ & $\begin{array}{l}\text { Pemenuhan evaluasi } \\
2 \%\end{array}$ \\
\hline & & & $\mathrm{b}$ & Kualitas evaluasi $5 \%$ \\
\hline & & & c & $\begin{array}{l}\text { Pemanfaatan hasil } \\
\text { evaluasi } 3 \%\end{array}$ \\
\hline \multirow[t]{3}{*}{5} & $\begin{array}{l}\text { Capaian } \\
\text { Kinerja }\end{array}$ & $20 \%$ & $a$ & $\begin{array}{lr}\text { Kinerja } & \text { yang } \\
\text { dilaporkan } & \text { (output) } \\
5 \% & \end{array}$ \\
\hline & & & $\mathrm{b}$ & $\begin{array}{ll}\text { Kinerja } & \text { yang } \\
\text { dilaporkan } & \\
\text { (outcomes) } 5 \% & \\
\end{array}$ \\
\hline & & & $\mathrm{c}$ & Kinerja Lainnya 10\% \\
\hline
\end{tabular}




\section{\begin{tabular}{|l|l|l|}
\hline Total & $100 \%$ \\
\hline
\end{tabular}}

\section{Good Governance}

Menurut Mardiasmo, 2002, Governance dapat diartikan sebagai cara mengelola urusan-urusan publik. Dalam buku ini, menurut World Bank definisi Good Governance sebagai suatu penyelenggaraan manajemen pembangunan yang solid dan bertanggung jawab yang sejalan dengan prinsip demokrasi dan pasar yang efisien, penghindaran salah alokasi dana investasi dan pencegahan korupsi baik secara politik maupun administratif, menjalankan disiplin anggaran serta penciptaan legal and political framework bagi tumbuhnya aktifitas usaha.

Menurut UNDP dalam Mardiasmo, 2002 memberikan beberapa karakteristik pelaksanaan good governance meliputi :

a. Participation, keterlibatan masyarakat dalam pembuatan keputusan baik secara langsung maupun tidak langsung melalui lembaga perwakilan yang dapat menyalurkan aspirasinya.

b. Rule of law, kerangka hukum yang adil dan dilaksanakan tanpa pandang bulu.

c. Tranparancy, dibangun atas dasar kebebasan memperoleh informasi.

d. Responsiveness, lembaga-lembaga public harus cepat dan tanggap dalam melayani stakeholder

e. Consensus orientation, berorientasi pada kepentingan masyarakat yang lebih luas.

f. Equity, setiap masyarakat memiliki kesempatan yang sama untuk memperoleh kesejahteraan dan keadilan.

g. Efficiency and Effectiveness, pengelolaan sumber daya publik dilakukan secara berdaya guna (efisien) dan berhasil guna (efektif).

h. Accountability, pertanggungjawaban kepada publik atas setiap aktifitas yang dilakukan

i. Strategic vision, penyelenggara pemerintah dan masyarakat harus memiliki visi jauh ke depan.

\section{Analisa dan Pembahasan}

Sebagai gambaran hasil evaluasi laporan akuntabilitas kinerja Politeknik Negeri Padang tahun 2011 yang telah dikeluarkan oleh Direktorat Jenderal Pendidikan Tinggi Kementerian Pendidikan dan Kebudayaan pada Desember 2012 dinyatakan bahwa Politeknik Negeri Padang memperoleh nilai Cukup Baik (Memadai), ada beberapa yang perlu diperbaiki namun tidak hal yang mendasar.

Namun dari hasil pengamatan, evaluasi dan wawancara yang penulis lakukan terhadap LAKIP Politeknik Negeri Padang untuk tahun 2012 dan 2013 sudah mengalami peningkatan. Dengan menggunakan kertas kerja evaluasi akuntabilitas kinerja instansi pemerintah berdasarkan Peraturan Menteri Negara Pendayagunaan Aparatur Negara dan Reformasi Birokrasi Nomor 13 Tahun 2010 tentang Petunjuk Pelaksanaan Evaluasi Akuntabilitas Kinerja Instansi Pemerintah, dan juga menggunakan datadata yang didapat baik berupa informasi dan laporan dalam bentuk LAKIP PNP, maka dapat disimpulkan hal-hal berikut :

A. Komponen Perencanaan Kinerja

Sub Komponen Renstra

a) Renstra sudah menggambarkan dengan jelas visi, misi, tujuan, sasaran, program, indikator kinerja sasaran dan target jangka menengah dan sudah mengacu kepada Renstra di atasnya.

b) Sasaran strategis yang ditetapkan sudah berorientasi pada hasil.

c) Mengenai implementasi Renstra sudah digunakan dalam acuan untuk penyusunan dokumen perencanaan tahunan dan telah telah dilakukan reviu secara berkala.

Sub Komponen Perencanaan Kinerja Tahunan (RKT)

a) Dokumen RKT telah memuat sasaran, program, indikator, kinerja sasaran dan target jangka pendek yang telah disusun sebelum mengajukan anggaran.

b) Dokumen RKT dapat dikatakan sudah selaras dengan dokumen Renstra. 
Sub Komponen Penetapan Kinerja (PK)

a. Dokumen PK PNP telah disusun setelah anggaran disetujui yang memuat sasaran, program, indikator kinerja dan target jangka pendek.

b. Namun Penetapan Kinerja unit kerja belum disusun.

B. Komponen Pengukuran Kinerja Telah terdapat indikator kinerja utama (IKU) sebagai ukuran kinerja secara formal, namun IKU unit kerja belum disusun.

C. Komponen pelaporan kinerja

a) Pemenuhan pelaporan, dokumen LAKIP Politeknik Negeri Padang telah disampaikan tepat waktu ke Direktorat Jenderal Pendidikan Tinggi.

b) Penyajian informasi kinerja, LAKIP telah menyajikan mengenai kemajuan pencapaian target jangka menengah

c) Pemanfaatan, informasi yang disajikan sudah digunakan dalam perbaikan perencanaan, perbaikan pelaksanaan program dan kegiatan organisasi, peningkatan kinerja dan untuk penilaian kinerja.

D. Komponen Evaluasi Kinerja

Dengan adanya Permenpan dapat digunakan sebagai pedoman evaluasi akuntabilitas kinerja. Evaluasi akuntabilitas kinerja atas unit kerja di lingkungan Politeknik Negeri Padang belum dilakukan, sehingga belum tersedianya penilaian atas akuntabilitas kinerja unit kerja tersebut, meskipun tetap ada evaluasi program, namun hal tersebut hanya terbatas pada program kegiatan saja.

E. Komponen Pencapaian Sasaran/ Kinerja Organisasi.

a) Target kinerja output dan outcome belum seluruhnya dapat tercapai

Selain hal di atas, pengukuran kinerja terhadap kegiatan pada Politeknik Negeri Padang dapat terlihat secara langsung dari realisasi anggaran (daya serap anggarannya).
Daya serap (realisasi anggaran) Politeknik Negeri Padang pada tahun 2012 sebesar 90,97\% sedangkan pada tahun 2013 menjadi 83,31\%. Daya serap ini mengalami penurunan jika dibandingkan pada tahun 2012. Penyebab terjadinya hal ini dapat dilihat pada tahun 2013 Politeknik Negeri Padang dalam melaksanakan program dan kegiatan untuk mencapai sasaran, tidak mengalami kendala yang berarti. Namun ada beberapa kegiatan yang tidak dapat dilaksanakan seperti kegiatan Program PEDP dan berapa kegiatan yang menggunakan dana PNBP. Beberapa kegiatan yang tidak dapat dilaksanakan seperti pencapaian sasaran Jumlah Laporan Program Pengembang Program PEDP, Jumlah Dokumen Belajar Mengajar Program PEDP, Jumlah Laporan Pelatihan/Lokakarya Program PEDP dan Jumlah Bulan Layanan PT Untuk Mendukung Manajemen Pelaksanaan Hibah.

Tidak tercapainya beberapa indikator kinerja tersebut karena proses pencairan dana PEDP yang cukup lama sehingga sampai akhir tahun anggaran kegiatan tidak bisa dilaksanakan. Sedangkan sasaran indikator kinerja Jumlah Buku Pustaka Pendukung Pembelajaran Swadana dan Jumlah Kendaraan Bermotor Pendukung Layanan Perkantoran Swadana tidak dapat terlaksana karena realisasi PNPB yang tidak mencukupi untuk melaksanakan kegiatan tersebut, sehingga pelaksanaan kegiatan yang telah dianggarkan tersebut tidak dapat terlaksana dengan semestinya. Selain beberapa program kerja yang tidak dapat dilaksanakan, ada beberapa kegiatan yang pencapaian anggaranya kurang dari $90 \%$ sehingga hal ini mempengaruhi daya serap anggaran secara keseluruhannya.

Hasil LAKIP dari objek yang diteliti dapat disimpulkan bahwa sudah menerapkan prinsip-prinsip Good Governance, atau dengan kata lain LAKIP mampu mewujudkan Good Governance pada PNP. Hal ini dapat dijabarkan sebagai berikut :

1) Participation, dalam artian keterlibatan semua pihak dalam penyusunan dan pelaksanaan LAKIP ini sudah dikatakan cukup 
baik. Hal ini bisa dilihat dari penyusunan dan pelaksanaan LAKIP di Politeknik Negeri Padang sudah melibatkan semua unsur atau unit yang ada, walaupun secara evaluasi terlihat keterlibatan pihak dan unsurnya masih kecil.

2) Tranparancy, maksudnya semua informasi sudah disajikan dengan lengkap. Di PNP penyediaan informasi sudah memadai dan dapat dimengerti dan dipantau.

3) Accountability

Pertanggungjawaban kepada publik atas setiap aktifitas yang dilakukan sudah terlaksana, dimana pertanggungjawaban kepada pimpinan yang lebih tinggi dalam hal ini Direktorat Jenderal Pendidikan Tinggi sudah dilaporkan secara tepat waktu.

4) Efficiency and Effectiveness

Dalam LAKIP ini sudah tergambar bahwa pengelolaan sumber daya publik telah dilakukan secara berdaya guna dan berhasil guna. Hal ini juga dapat dilihat dari tingkat ketercapaian terhadap hal-hal yang menjadi tujuan perguruan tinggi ini.

5) Strategic vision

Hal ini sudah tergambar dengan baik karena dalam LAKIP PNP sudah tertera dan terlihat visi, misi dan tujuan serta sasaran dan apa program atau kegiatan setiap tahunnya untuk mewujudkan visi dan misi yang telah ditetapkan.

Dalam pelaksanaan LAKIP ini masih mengalami beberapa hambatan yang menjadi permasalahan/kendala yaitu :

1. Masalah kemampuan Sumber Daya Manusia (SDM) yang terkait dengan perencanaan, pelaksanaan anggaran dan pelaporan.

Berdasarkan penelitian yang pernah penulis lakukan bahwa kapasitas dan kemampuan Sumber Daya Manusia (SDM) akan mempengaruhi terhadap keterandalan dan ketepatwaktuan laporan yang dibuat, seperti LAKIP dan laporan lainnya.
Oleh karena itu penempatan SDM yang berkualitas pada bagian ini sangat mendukung terwujudnya pencapaian good governance. Karena kesalahan dan tidak tepatnya dalam penganggaran maka akan berdampak tidak tercapainya yang diharapkan. Begitu juga dalam hal pelaksaan dan pengawasannya. SDM yang berkualitas dan kompeten sangat dibutuhkan.

2. Komitmen semua pihak untuk mencapai tujuan yang telah ditetapkan masih belum optimal. Salah satu penyebabnya adalah karena masih kurangnya komunikasi dan koordinasi dari masing-masing bagian/unit/jurusan secara intensif sehingga permasalahan bisa timbul karena tidak adanya komitmen bersama yang tercipta dengan baik.

3. Terkadang PAGU definitif keluar secara dadakan sehingga mengakibatkan koordinasi antara pihak perencanaan dengan pihak yang terkait menjadi kurang efektif sehingga mengakibatkan usulan program kurang terakomodir dengan baik. Oleh karena itu dibutuhkan tim yang handal dan dapat bekerja secara cepat dan tepat.

Kesimpulan

LAKIP merupakan bagian dari implementasi Sistem Akuntabilitas KInerja Instansi Pemerintah (SAKIP). Dengan adanya LAKIP ini dapat digunakan untuk mengukur kinerja suatu organisasi. LAKIP merupakan media akuntabilitas setiap organisasi. SAKIP dapat mendukung terciptanya good governance yang bertujuan untuk meningkatkan tata kelola pemerintahan yang bersih dan akuntabel, sehingga akan mampu menunjukkan akuntabilitas publik kepada masyarakat yang akhirnya meningkatkan kualitas pelayanan publik.

LAKIP PNP yang dianalisa adalah tahun 2013 dan 2014, sedangkan komponen yang dinilai adalah adalah perencanaan kinerja (Renstra, Perencanaan Kinerja Tahunan, Penetapan Kinerja), pengukuran kinerja, pelaporan kinerja dan evaluasi kinerja serta komponen pencapaian sasaran/kinerja organisasi. 
Hasilya diperoleh bahwa LAKIP Politeknik Negeri Padang cukup baik, hal ini dapat dilihat dari tercapainya visi dan misi yang telah ditetapkan di awal.

\section{Daftar Pustaka}

Badan Pengawas Keuangan dan Pembangunan. 2007. Modul Akuntabilitas Instansi Pemerintah. Pusat Pendidikan dan Pelatihan. Badan Pengawasan Keuangan dan Pembangunan.

Indra Bastian, 2006. Akuntansi Sektor Publik, Penerbit Erlangga. Jakarta

Mardiasmo, 2002. Otonomi dan Manajemen Keuangan Daerah, Penerbit ANDI. Yogyakarta

Mardiasmo, 2004. Akuntansi Sektor Publik, Penerbit ANDI. Yogyakarta

Mardiasmo, 2006. Perwujudan Transparansi dan Akuntabilitas Publik melalui Akuntansi Sektor Publik : Suatu Sarana Good Governance, Jurnal Akuntansi Pemerintah, vol 2 nomor 1 , hal 1 17.

Mahmudi, 2007. Manajemen Kinerja Sektor Publik. UPP. STIM YKPN. Yogyakarta.

Mohamad Mahsun dkk. 2006. Akuntansi Sektor Publik. BPFE. Yogyakarta.

Instruksi Presiden Republik Indonesia Nomor 7 Tahun 1999 tentang Akuntabilitas Kinerja Instansi Pemerintah.

PP No. 60 tahun 1999 tentang Pendidikan Tinggi

Peraturan Menteri Negara Pendayagunaan Aparatur Negara dan Reformasi Birokrasi Nomor 13 Tahun 2010 tentang Petunjuk Pelaksanaan Evaluasi Akuntabilitas Kinerja Instansi Pemerintah Tahun 2010

\section{Peraturan Menteri Negara} Pendayagunaan Apartaur Negara dan Reformasi Birokrasi Nomor 29
Tahun 2010 tentang Pedoman Penyusunan Penetapan Kinerja dan Pelaporan Akuntabilitas Kinerja Instansi Pemerintah

TAP MPR RI No XI/MPR/1998 tentang penyelenggaraan negara yang bersih dan bebas korupsi, kolusi dan nepotisme.

Laporan Akuntabilitas Kinerja Instansi Pemerintah (LAKIP) Politeknik Negeri Padang

Laporan Akuntabilitas Kinerja Instansi Pemerintah (LAKIP) Politeknik Pertanian Negeri Payakumbuh

Laporan Akuntabilitas Kinerja Instans Pemerintah (LAKIP) Universitas Andalas Padang

Laporan Akuntabilitas Kinerja Instansi Pemerintah (LAKIP) Universitas Negeri Padang Padang 